\title{
The Epigraphy of Honours: Epigraphic Habit and Honorific Culture at Delphi
}

Honorific culture is an important part of every city's epigraphic habit, but in Delphi it is particularly remarkable. ${ }^{1}$ For over 1000 years, from the early sixth century ВСЕ to the late fourth century CE, the local history of Delphi was one of honours and benefactions and of relationships with both the new territorial powers and the old inhabitants of the Mediterranean world. Delphic honorific texts (of all types) constitute over $43 \%$ of the total number of surviving inscriptions. Similarly high percentages of honorific documents are also discernible elsewhere, for instance in Olympia, Miletos, Ephesos, and Pergamon. ${ }^{2}$ In these places the evidence reveals that tituli honorarii are the most prevalent, while in Delphi honorary decrees constitute the vast majority of honorific texts. ${ }^{3}$ In this chapter, I pose the following questions regarding the honorific culture at Delphi: Why did the honorific culture constitute such a large share of epigraphic production? What internal and/or external factors shaped and influenced it? Was it a permanent trend or was it limited to particular periods? How did the Delphic honorific culture correspond to honorific habits in other poleis? In order to answer these questions, it is necessary to look at the entire epigraphical output at Delphi, starting from c. 6оо вCE when it began.

The term 'epigraphic habit' was popularised by MacMullen in 1982 to describe the practice of recording the actions of Romans on stone. ${ }^{4}$ Since the publication of MacMullen's paper, scholars have come to regard inscriptional activity as a cultural choice, rather than as a matter of routine. Over time, the phrase 'epigraphic habit' has been used more loosely, not to denote a habit that extends across public and private monuments, but to mark the increasing

1 This chapter is an expanded and more developed version of my article 'The epigraphic curve at Delphi', which is a part of the project 'Epigraphic culture in the Eastern Mediterranean in antiquity', published in Routledge 2020. Honorific and proxeny decrees (34,1\%), tituli honorarii $(8 \%)$ and topoi $(1 \%)$.

2 Komar 2020, 68-80 and Nawotka 2020c, 118-143.

3 I use the Latin name titulus honorarius instead of the equally common 'honorific inscription', since the latter may be somewhat misleading. See below.

4 MacMullen 1982, 233-246. Cf. Mrozek 1973, 113-118 and 1988, 61-64; Lassère 1973, 7-152. 
frequency with which public decisions and orders are inscribed. ${ }^{5}$ The term 'epigraphic habit' is gradually being superseded by the term 'epigraphic culture', which reflects more acutely the social context in which inscriptions were commissioned; however, in this book these terms are used interchangeably as they both equally refer to the chronological distribution of ancient inscriptions. The so-called 'epigraphic curve' remains a generally accepted term for a linear or other graphic representation of the chronological distribution of inscriptions. ${ }^{6}$

The idea of studying the frequency of ancient inscriptions is not in itself a new one. Until recently, however, most of this research has focused on the Roman empire ${ }^{7}$ and Athens. ${ }^{8}$ In his seminal study Bodel pointedly differentiates between 'the Roman epigraphic habit' and, in the plural, 'Greek epigraphic cultures. ${ }^{9}$ This distinction stems from a juxtaposition of the seemingly well-defined epigraphic habit of the Roman empire with the local peculiarities of the Greek world. The project, 'Epigraphic culture in the Eastern Mediterranean in antiquity', which is based on ten case studies that had a significant epigraphic output, supports Bodel's division into the single 'Roman epigraphic habit' and the plural 'Greek epigraphic habits.'10 The tabulation of inscriptions from the Eastern Mediterranean demonstrates divergent epigraphic cultures in this region. The overall picture of the epigraphic habit in the Eastern Mediterranean is certainly much more variegated than Roman epigraphic practice. For this reason it is particularly important to continue epigraphic study, which has the potential to develop an even richer understanding of the use of the inscribed medium in the history of the ancient Mediterranean. This chapter will discuss in detail the chronological distribution of inscriptions at Delphi and the local epigraphic habit.

At a minimal estimate, 1184 decrees and 281 tituli honorarii have been found at Delphi, out of a total of 3727 inscriptions. ${ }^{11}$ This database has been compiled

\footnotetext{
5 Osborne 2009, 103.

6 Trout 2009, 170-186.

$7 \quad$ Mrozek 1973; MacMullen 1982; Meyer 199o.

8 Hedrick 1999; Meyer 2013.

9 Bodel 2001, 1-56.

10 Nawotka 2020b, 2-3.

11 Inscriptions issued by the Delphic authorities but engraved outside of Delphi remain beyond the scope of this chapter. It is worth mentioning, however, that their total number is very limited. One of the most relevant texts is $I G \mathrm{II}^{2} 1136$ from Athens, which is an honorific inscription for the Athenian priestesses of Athena Polias. The Delphic polis also set up honorific portraits in Eretria (SEG 32.856) and Rome (IG XIV 1050 = IGUR I 25).
} 
from published texts and does not include unpublished inscriptions. ${ }^{12}$ The reader should therefore bear in mind that the data is to a certain degree provisional and liable to change as more inscriptions might be unearthed in the future. $251(7 \%)$ out of the 3727 texts are too fragmentary to provide any clarity on their date or type; therefore, this chapter focuses on the remaining 3476 documents. This number highlights how remarkable Delphi was in comparison with other poleis with regard to both the large amount of epigraphic material it produced and its surprisingly high percentage of datable texts. Only Athens and Ephesos produced more inscriptions than the small polis of Delphi; the documents of Ephesos, however, are very poorly dated. ${ }^{13}$ Athens set up more inscriptions than any other Greek polis for several reasons, including the availability of suitable marble, the rapid spread of democracy, and the city's role as the centre of the empire. Extensive excavations have also helped in uncovering the large amount of preserved inscribed material from Athens. ${ }^{14}$ Conversely, the large number of inscriptions from Delphi can be attributed to factors such as the introduction of abbreviated forms of decrees and the employment of built surfaces, rather than free-standing stelai, as media for inscriptions. ${ }^{15}$ These preserved monuments are in relatively good condition due to the fact that the later urban development at the sanctuary proved to be short-lived, with the site already being abandoned in the early seventh century CE. ${ }^{16}$ Furthermore, like Athens, the territory of Delphi has also been well excavated, even though the whereabouts of Delphi's foremost nekropoleis remain unknown. The fact that inscriptions were more or less inscribed on buildings in chronological order also helps with the dating of preserved texts. Moreover, many of the $c$. 25 oo decrees and manumissions include dating formulae which

12 The collection includes texts that can be found in the Packard Humanities Institute database, inscriptions from $F d D, C I D$ nos. I-IV, $S E G, S y l l^{3}$, and those published in journals (mainly the $\mathrm{BCH}$ and Klio). This book was finished before the fifth volume of Corpus des Inscriptions de Delphes (tome v: Les actes d'affranchissement, vol. ı: Prètrises I ̀̀ IX, nos. ${ }_{1-722)}$ by D. Mulliez was published, so the number of manumissions included here is a little lower than the one estimated by Mulliez (1341 texts).

13 Nawotka, Carless Unwin, Grzesik at al. 2020, 215-217. Boeotia as a region produced c. $5^{271}$ inscriptions, but no individual Boeotian city inscribed more texts than Delphi, see Szeląg 2020, 31-51.

14 Meyer 1990, 74-93; Hedrick 1999, 387-439.

15 For further discussion on this issue, see Chapters 5 and 6.

16 Pétridis $(1997,684-685)$ demonstrates the transformation of sacral Delphi into a secular early Christian city. 
have allowed lists of Delphic eponymous archons and priests to be recreated, which have improved the dating of inscriptions from other categories. ${ }^{17}$

The epigraphic habit at Delphi differed from that of other poleis in many important ways and can thus be defined as a subject on its own. The epigraphic culture of Delphi is unique since it can be explored from two perspectives: it can be discussed either as a habit of an individual polis, or as part of an international, Panhellenic context. The territory of Delphi served not only as a place where local civic bodies and private individuals displayed their epigraphic culture, but also as a trans-regional sanctuary. ${ }^{18}$ For instance, preserved statue bases set up by Delphic citizens constituted only $45 \%$ of portrait production, while the remaining $55 \%$ were variously set up by foreign communities, koina and private individuals. Admittedly the percentage of preserved decrees granted by Delphians $(85 \%)$ in comparison with other communities $(12 \%)^{19}$ is much higher, but still the participation of foreign agents within the honorific practice at Delphi has a global preeminence to a degree that is not attested anywhere else. The unique combination of both local and international factors constitutes one of the main features of the epigraphic habit at Delphi.

\subsection{Categories of Inscriptions}

Inscriptions from Delphi can be divided into the following main categories: (1) decrees (honorific decrees constitute most of the texts in this category);

(2) tituli honorarii; (3) manumission records; (4) dedications; and (5) other. The category entitled 'other' consists of those types of inscriptions that are attested in too few numbers to be included as a separate category, such as letters, building inscriptions, sculptor signatures, leges sacrae, and so forth. Until recently Delphi had not yielded a substantial number of funerary inscriptions, so that epitaphs are not distinguished as a separate type.

Standard patterns of Delphic decrees, both full and abbreviated, and tituli honorarii will be thoroughly discussed in Chapter 5 . Here it needs to be stressed that decrees (psephismata) constitute the minutes of the official proceedings of the assembly, council, and, albeit rarely, other civic bodies such as those presided over by damiourgo $i{ }^{20}$ these were erected in public space. The

\footnotetext{
17 Daux 1943b.

18 Rousset 2002.

19 The remaining $3 \%$ remain unattributed.

2 o $F d D 4.98$.
} 
greatest number of decrees from Delphi are honorific. These include proxeny decrees, which were widespread in the Hellenistic period, decrees honouring foreign judges and asylia decrees, as well as citizenship decrees, which were especially common in the Roman period. While decrees are always public acts, there is a substantial sub-category of private tituli honorarii in Delphi, which were often commissioned by a family member of the honorand and displayed within the civic space. In this volume, I have chosen to employ the Latin name titulus honorarius instead of the equally common 'honorific inscription', since the latter may be somewhat misleading; many decrees which convey honours on benefactors could also be called honorific inscriptions. In most cases tituli honorarii from Delphi are cut into the base of statues which were erected for deserving benefactors, but sometimes they are instead engraved on walls or stones which never supported a statue.

Manumission records, which represent the most numerous category of preserved inscriptions at Delphi, are always private acts, in contrast to public manumissions attested in Athens, ${ }^{21}$ Rhodes, ${ }^{22}$ and some Thessalian cities. ${ }^{23}$ In Delphic records, owners sold their slaves to a divinity for the purposes of freedom; the slave entrusted the purchase-money to the god on the condition that he/she be free. Thus, a slave's freedom was attained by a fictive dedication or sale to a divinity; in Thessaly and Chaironeia, by contrast, manumissions were secular acts where slave owners freed their slaves by a simple declaration or proclamation or otherwise ordered the manumission in their last will. ${ }^{24}$ Modes of manumitting slaves similar to that attested at Delphi have been found in central and western Greece, the Peloponnese, and in Asia Minor. ${ }^{25}$

The highly formulaic language of Delphic manumissions makes them easy to work with and easy to reconstruct. They open with the dating formula, which cites the name of the eponymous archon of Delphi and the month (SGDI 1689,

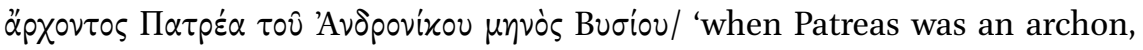
in the month Bysios'). If the slave's master was not from Delphi, the dating formula might also include the name of the eponymous official of the master's hometown. The text continues with the verb $\dot{\alpha} \pi \varepsilon \dot{\delta} \delta \tau 0 / \dot{\alpha} \pi \varepsilon \dot{\delta} 0 v \tau 0$ ('sold/ gave

\footnotetext{
21 Ar. Ra. 693-694.

22 D.S. $20.100,1-4$.

$23 B C H$ 35.1911.231-7, A col. II. For the full categorisation of Greek manumissions, see Calderini 1908.

24 Parker and Obbink 2000, 441-442; Zelnick-Abramovitz 2013, 30, fn. 7. For the donation of slaves to deities, see Ricl 2001, 127-16o; for the consecration of slaves in Boeotia, see Darmezin 1999.

Calderini 1908, 103; Bömer 196o, 18-111; Zelnick-Abramovitz 2005, 86-87.
} 
up'), followed by the name(s) of the owner(s) in the nominative case (SGDI 1689, $\dot{\alpha} \pi \dot{\varepsilon}[\delta] \circ \tau \circ \Sigma \omega \sigma i \alpha \varsigma \Sigma \omega \sigma i \alpha /$ 'Sosias, son of Sosias sold/ gave up') a reference

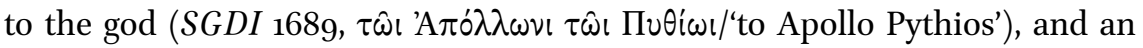
identification of the slave in terms of his/her sex, age, and ethnic background

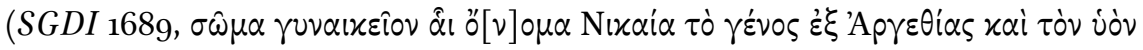
$\alpha \dot{\tau} \tau \hat{\varsigma} \varsigma^{\prime} I \sigma \theta \mu o ́ v /$ 'a female slave (literally - a female body), whose name is Nikaia, by origin of Argethia, and her son Isthmos'). Next there follows the price of a

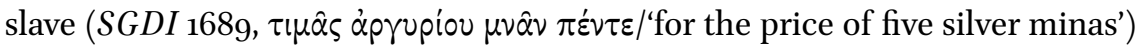

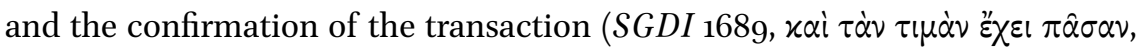

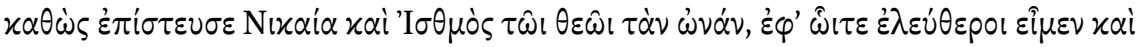

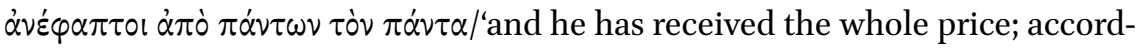
ingly, Nikaia and Isthmos have entrusted the sale to the god, on the condition that they be free and untouchable by anyone for all their lives'). The guaran$\operatorname{tor}(s)(\beta \varepsilon \beta \alpha \iota \omega \tau \dot{s} s)$ and witnesses ( $\mu \alpha \dot{\rho} \tau \tau \rho \rho \imath)$ of the purchase are usually named at the end of the inscription. ${ }^{26}$

Another category of inscriptions are dedications. This includes a broad range of texts of religious significance which record the offerings made to the gods as acts of piety, often in conjunction with petitions or thanksgivings. Votive inscriptions (ex-votos or donaria) are dedications made in fulfillment of a vow. ${ }^{27} \mathrm{~A}$ typical dedication has the name of a god in the dative and the name of the dedicator in the nominative (if a dedicator is named at all), as in this Hellenistic Rhodian dedication:

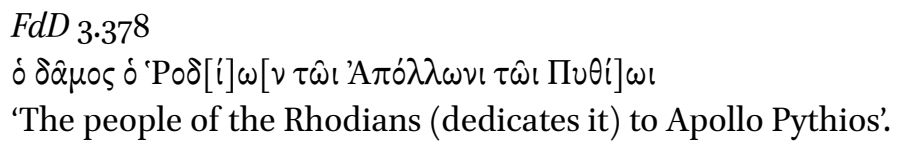

This category also comprises inscriptions on altars, such as, for example, the following famous Chian dedication from the fifth century вСЕ:

FdD 3.212

Xîo 'A $\pi$ ó $\lambda \lambda \omega \nu$ เ òv $\beta \omega \mu$ óv

'The Chians (dedicate) this altar to Apollo'

$26 \quad$ McLean 2002, 295-206.
$27 \quad$ McLean 2002, 184. 


\subsection{The Epigraphic Curve at Delphi and the Spread of Honorific Culture}

The following table presents the categories of inscriptions from Delphi. All datable material is catalogued by century and, when possible, by quarter-century. ${ }^{28}$ Figure 1 covers $93,5 \%$ of all data in the sample, whereas Figure 2 contains $78,7 \%$. Increased chronological precision thus comes at a price.

TABLE 1 Categories of inscriptions from Delphi

\begin{tabular}{lccc}
$\begin{array}{l}\text { Type of } \\
\text { inscriptions }\end{array}$ & $\begin{array}{l}\text { No. of } \\
\text { inscriptions }\end{array}$ & $\begin{array}{l}\text { No. of inscriptions } \\
\text { dated by century }\end{array}$ & $\begin{array}{l}\text { No. of inscriptions dated } \\
\text { by quarter-century }\end{array}$ \\
\hline $\begin{array}{l}\text { Manumission } \\
\text { records }\end{array}$ & $1197(34,4 \%)$ & $1161(97 \%)$ & $958(80 \%)$ \\
$\begin{array}{l}\text { Decrees } \\
\text { Tituli honorarii }\end{array}$ & $1184(34,1 \%)$ & $1085(91,6 \%)$ & $951(80,3 \%)$ \\
$\begin{array}{l}\text { Dedications } \\
\text { Other }\end{array}$ & $218(6,1 \%)$ & $265(94,3 \%)$ & $236(84 \%)$ \\
Total & $596(17,1 \%)$ & $203(93,1 \%)$ & $151(69,3 \%)$ \\
\hline
\end{tabular}

a Most decrees granted by the Delphic polis are recorded in abbreviated form; see Grzesik 2013, 157-162. See also Chapter 5.1.1.

28 The methodology used for dating inscriptions follows Nawotka and the project 'Epigraphic culture in the Eastern Mediterranean in antiquity'. As he writes: '[i]n this paper datable inscriptions are those whose dates can be established with precision either on the basis of internal information (e.g. by the name of an eponymic magistrate, king, emperor etc.) or through palaeographic criteria (...) Inscriptions that are dated by the editors as "Hellenistic" or "Imperial" have not been considered. (...) Presenting material in 25-year brackets is akin to MacMullen's 20-year brackets, the 25-year brackets of Le Bohec, Meyer, Cherry and Hedrick and in line with Hochscheid's arrangement of archaic and classical sculpture in Athens. (52) This division of material is not only a matter of convention. It stems primarily from the desire to interpret minima and maxima of the epigraphic curve with reference to historical events evolving within a generation, or within the reign of a king or emperor who might have affected epigraphic production in a particular city. (53) Graphs drawn on the basis of tabulation by century present a flatter image and are less susceptible to historical interpretation' (Nawotka 2020b, 23-24). 


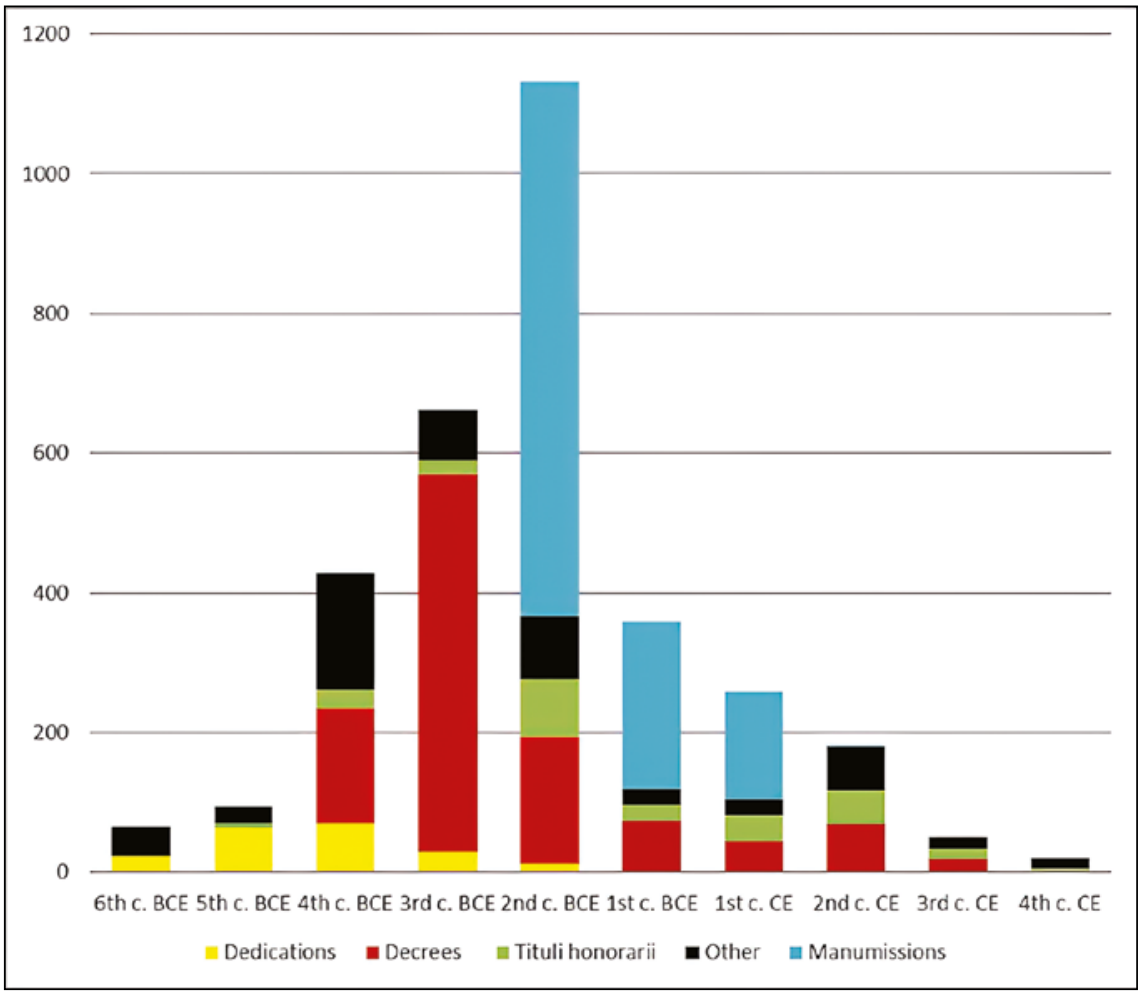

FIGURE 1 Inscriptions from Delphi by century (sixth century BCE-fourth century CE)

The epigraphic habit at Delphi was certainly not static, as can be seen from the fluctuations in the graphs that chart the number of datable inscriptions by century (Figure 1) and quarter-century (Figure 2) respectively.

The earliest three inscriptions found in Delphi are dated to $c a$. 6оо вСЕ (Figure 2). They are dedications inscribed on bronze cauldrons; their provenance and dedicators are uncertain. ${ }^{29}$ The first significant peak in inscriptions at Delphi is discernible in the third quarter of the sixth century вСЕ. This development in the epigraphic habit can be linked to changes in the local topography and the erection of the first treasuries, which filled up the available public space, and were later used as surfaces for inscriptions (see Appendix 1). ${ }^{30}$ The earliest public inscriptions concern the erection of the Knidian ${ }^{31}$ and

\footnotetext{
29 SEG 30.503-505.

$30 \quad$ Partida 2000.

$31 \quad F d D 1.289\left(55^{\circ}-525\right.$ ВСЕ $)$.
} 


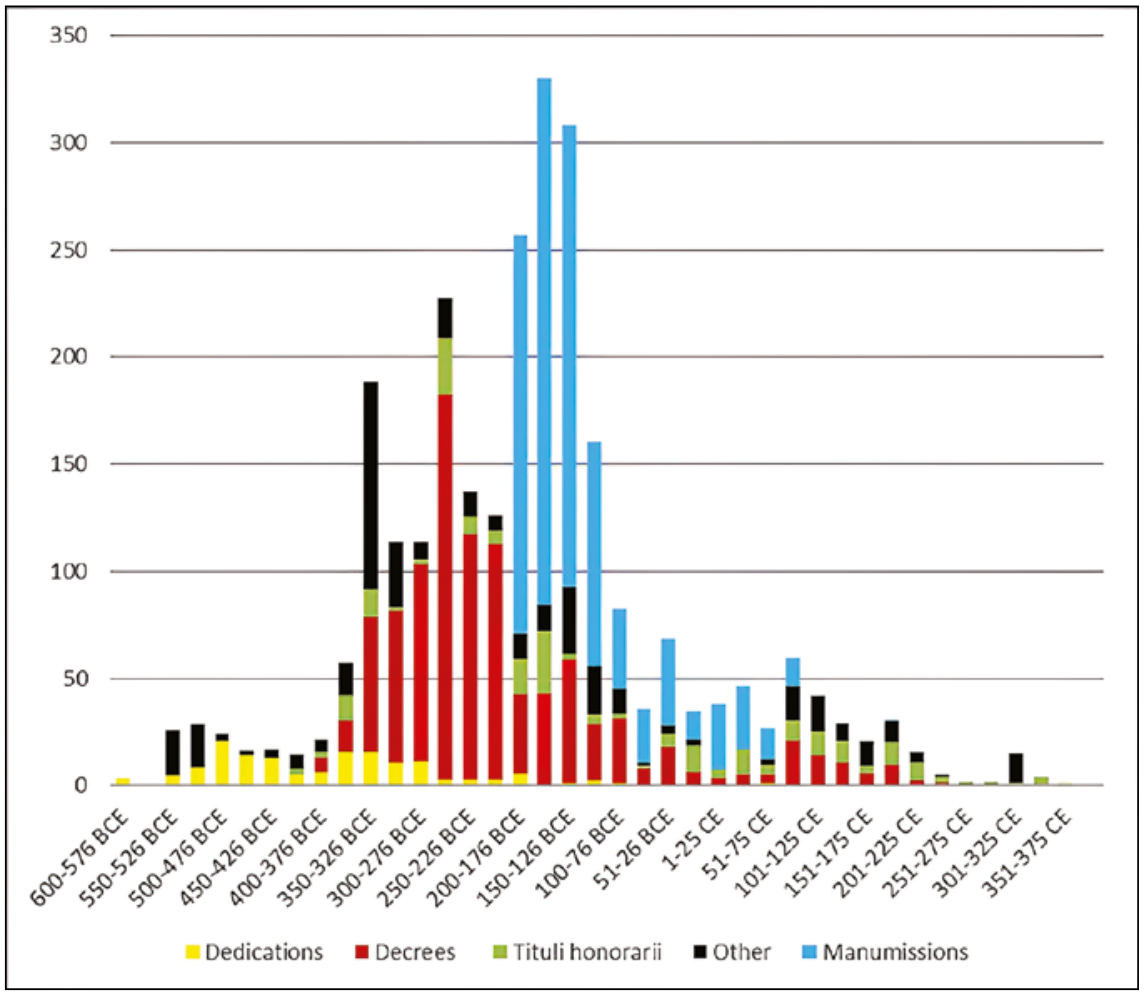

FIGURE 2 Inscriptions from Delphi by quarter-century (sixth century BCE-fourth century CE)

Corinthian $^{32}$ treasuries, whilst forty texts dated to $c a .530-520$ BCE (catalogued as 'other') derive from the frieze of the Siphnian Treasury. ${ }^{33}$ The number of surviving inscriptions from this period is small; therefore, any conclusions should be made tentatively. It seems correct, however, to state that the epigraphic habit spread at Delphi when surfaces suitable for writing on (i.e. building walls) and the relevant individuals (i.e. dedicators) appeared. The inauguration of the Pythian Games in 586 BCE additionally ensured a steady stream of recurring visitors to Delphi. Consequently, throughout the following centuries the sanctuary became an excellent showground for dedications, decrees and honorific monuments.

$32 \quad F d D 3.153(c .540$ ВСЕ $)$.

$33 \quad B C H$ 109.1985.79-103. For the Siphnian Treasury, see Neer (2001, 273-336) where the author tests the hypothesis that the function of a treasury is to provide a civic frame for ostentatious dedications by wealthy citizens and in effect, to 'nationalise' votives. 
The sacred and international character of the area and its surroundings influenced the categories of inscriptions engraved upon Delphic walls. In the fifth century вСЕ, dedications were the predominant type of inscription. ${ }^{34}$ Changes in the epigraphic culture cannot be isolated from the political history of the region and further afield; victory over the Persians and the rivalry between Athens and Sparta that existed prior to the Peloponnesian War are mirrored in the temenos in the form of spolia that were looted during war, ${ }^{35}$ new buildings, and outstanding votive offerings. ${ }^{36}$ During the sixth century BCE, Olympia served as an international arena for displaying all types of booty, but from the fifth century onwards Delphi took over the mantle and became the prime location where military triumphs and personal achievements were showcased. ${ }^{37}$ Since Delphi had an international and not a local character, citizens of the Greek world started to dedicate honorific statues within the temenos earlier than the local Delphian inhabitants. Portraits were awarded as early as the fifth century вСЕ by foreigners who wanted to commemorate prominent military leaders, ${ }^{38}$ heroes, ${ }^{39}$ victorious athletes ${ }^{40}$ and other outstanding individuals from their own communities in the 'shared' Delphic shrine (Figure 3).

The earliest epigraphic material which attests to the spread of the Delphic decree culture is dated to the beginning of the fourth century вСЕ (Figure 4).41 At more or less the same time decrees granted by the Amphictyony and other poleis appeared at Delphi. ${ }^{42}$ Decrees from the neighbouring Boeotian poleis are unknown before the late fourth century ВСE, Oropos began to inscribe decrees in the 33os, while the Boeotian League started to produce them in the $3^{60 \text { os. }^{43}}$ It seems, therefore, that the fourth century BCE was a crucial period with regard to the introduction of epigraphy into the honorific sphere of Delphi and central Greece. Literary sources, however, date the Delphic decree habit to the archaic period. According to Herodotus, the citizens of Delphi

34 On transition from votive statues to honorific portraits, see Keesling 2017, 19-52.

35 Partida 2000, 48-70; Guide 2015, 151-166.

36 For dedications and treasuries at Delphi in the archaic and classical periods, see Vatin 1991; Jacquemin 1999; Partida 2000; Scott 2010, App. A-F; Biard 2016, 61-69; Krumeich 2017, 211-251.

37 Komar 2020, 68-80.

38 Paus. 10.10.1-2 (Miltiades statue); Paus. 10.15.4 (cavalry leaders from Pherai); Paus 10.13.10 and 10.10.6-8 (a group statue of soldiers from Tarentum).

39 Paus. 10.13.5 (the heroes of the Trojan War); Paus. 10.10.1-2 (Athenian local heroes, e.g. Erechtheus).

$40 \quad S y l l^{3} 82$ (the winner of pankration).

$41 \quad B C H$ 93.1969.92; $F d D$ 4.374. On the decree culture of the Megarid, see Liddel 2009, 411-436.

42 SEG 44.425; CID 1.12.

43 Liddel 2009, 418. 


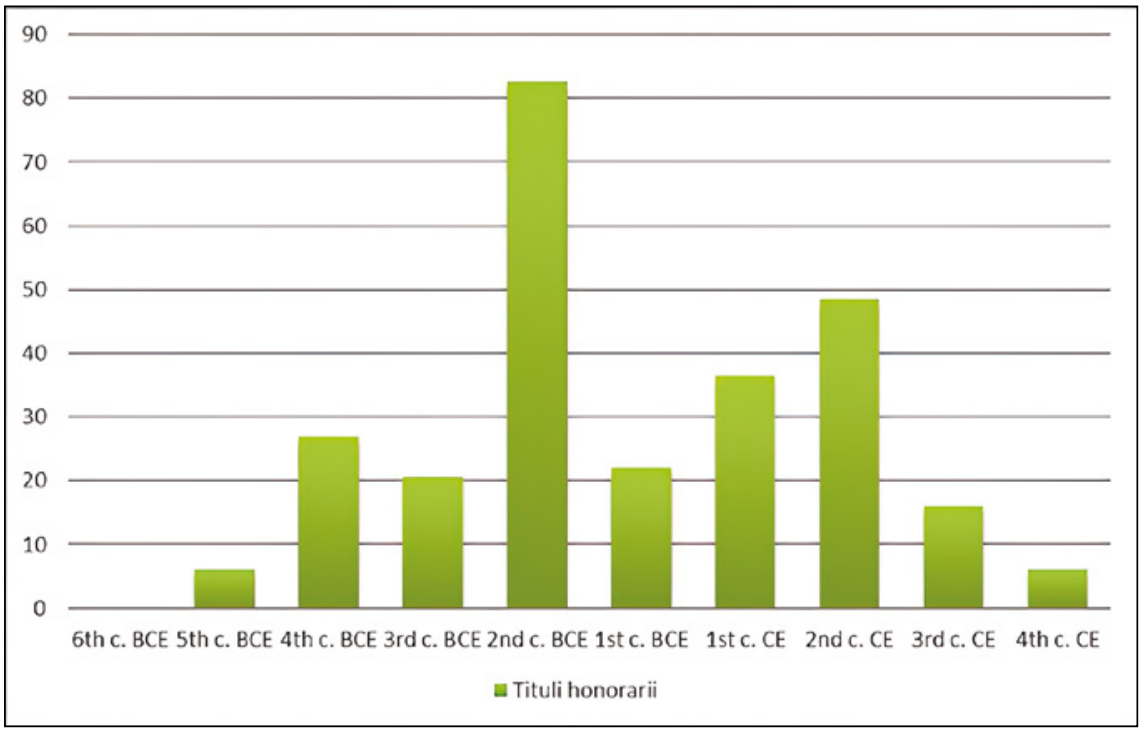

FIGURE 3 Tituli honorarii from Delphi by century

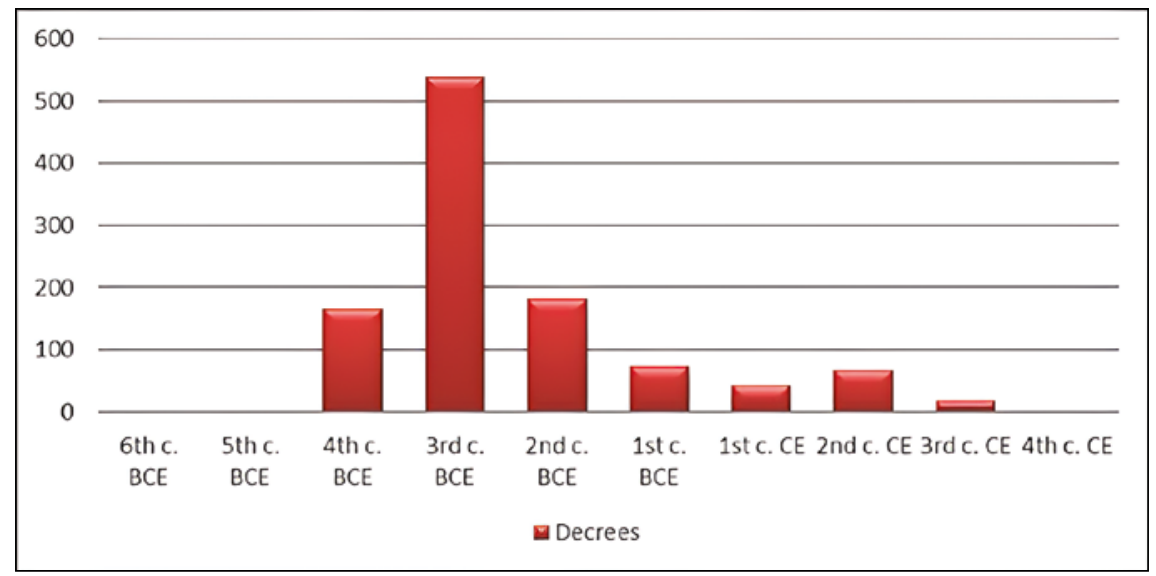

FIGURE 4 Decree production at Delphi by century

granted Croesus and all Lydians promanteia and other Delphic privileges in c. 543 BCE. ${ }^{44}$ Wilhelm Dittenberger and the editors of the Sammlung der griechischen Dialekt-Inschriften presented the text that appears in Herodotus' work as a text from an actual decree, although the stone which bore the

44 Hdt. 1.54. 
inscription has never been found; 45 the decree was, however, not included in later volumes of $F d D$. That there is a 150-year gap between the decree mentioned by Herodotus and the next set of datable stone-inscribed decrees is puzzling. The fragment preserved in Herodotus is similar in wording to the texts of later abbreviated Delphic decrees, which suggests that Herodotus must have heard of and may even have seen this decree. The answer may lie in the fact that, in the late archaic period, Delphic self-awareness became stronger, as in the second half of the fifth century BCE the first public regulations regarding religious matters were attested, revealing further activity by Delphi's civic bodies. ${ }^{46}$ It is therefore possible that the Delphians were already issuing decrees in the archaic period, inasmuch as the custom was widespread outside of Delphi at that time. Until the beginning of the fourth century BCE, however, decrees were not inscribed in stone, but on wood, while the decision to award honours was proclaimed in the assembly without being inscribed for public exhibition. ${ }^{47}$ Regardless of which date we accept as the starting point for the decree culture at Delphi, it is in the second half of the fourth century BCE that a significant peak in decree production took place and for that reason this period deserves further attention (Figure 5).

The rapid growth of the decree culture at the midpoint of the fourth century BCE can be attributed to the spread of democracy in Delphi at around the same time. ${ }^{48}$ Studies by Gauthier on governance at Delphi indicate that throughout the entire second century BCE (and possibly as early as the third century BCE) it operated within a democratic system. ${ }^{49}$ Analysis of the formulae of Delphic public documents offers some further insights. From the mid-fourth century вСЕ, all Delphic citizens were regarded as equal, meaning that they were entitled to the same prerogatives and were afforded a privileged position within the sanctuary. ${ }^{50}$ The Delphic assembly was the ultimate civic body, with

$45 S y / l^{3} 7$ and SGDI 2698. Perhaps it never existed. The credibility of Herodotus' other testimony concerning the famous testing of the major Greek oracles by Croesus has often been questioned; see Schachter 1981, 21. The new epigram discussed in detail by Papazarkadas (2014, 241-242) appears to vindicate Herodotus, insofar as he shows that there was a connection between Apollo Ismenios and Amphiaraos at Thebes.

46 E.g. CID 1.4-6. These inscriptions are catalogued as 'other'.

47 On euergetism in the archaic period, see Domingo Gygax 2016, 58-59 and 108-109.

48 The development of euergetism is often linked to the transformation of democracy in the Hellenistic period, see Reden 122-125.

49 This is stressed, for instance, by the prerogatives of the assembly and the equality of all citizens. Gauthier 2000, 109-139.

50 The equality of all Delphians is demonstrated by the formulae found in proxeny decrees:

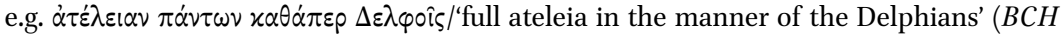
19.1895.393, c. 34 О вСЕ, $B C H$ 23.1899.520,6, 350-30о вСЕ; FdD 4.411 II, 262/1 вСЕ, FdD 


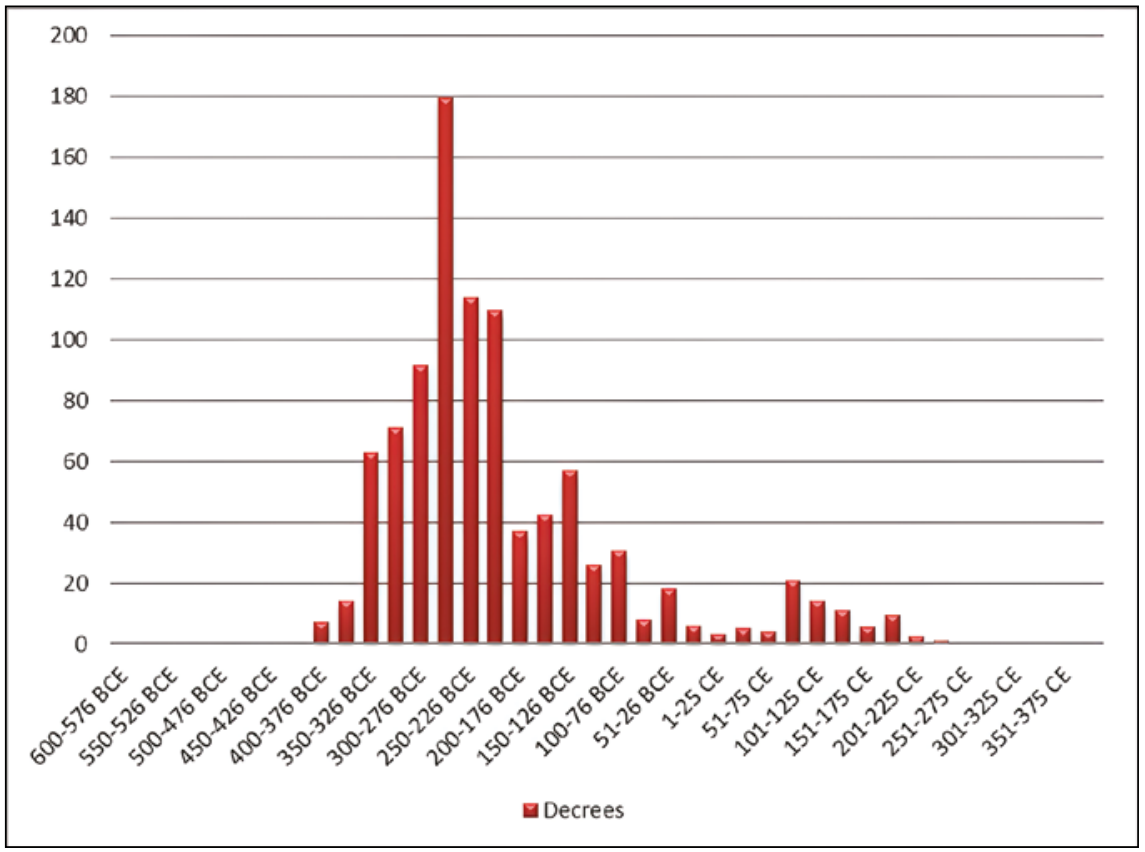

FIGURE 5 Decree production at Delphi by quarter-century

legislative prerogatives, while the council most probably acted only as an advisory board, as bouleumatic or probouleumatic decrees are not attested before the end of the first century CE. ${ }^{51}$ Taken as a whole, the evidence suggests that a democratic atmosphere existed in Delphi after 35 O BCE.

Another significant trend within the fourth century BCE epigraphic output at Delphi is that, after the Third Sacred War, the honorific culture gained a strong Macedonian flavour. The honorific portraits of Philip II, ${ }^{52}$ Archon of Pella, the satrap of Babylonia, ${ }^{53}$ and Alexandros, son of Polyperchon, ${ }^{54}$ together

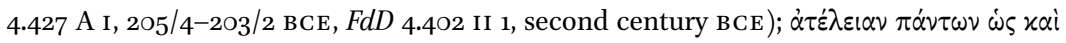

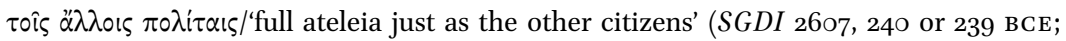

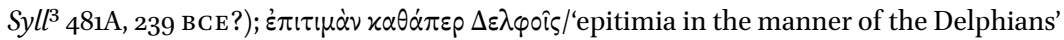
(FdD 1.391, c. 36о-355 вСЕ; BCH 64/65.1940/1.94, 330-320 вСЕ; FdD 1.14, c. 234/3 вСЕ, FdD

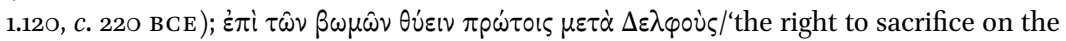
altars immediately after the Delphians' ( $F d D$ 2.18, 30о-20о вСЕ, $F d D$ 2.21, 300-20о вСЕ);

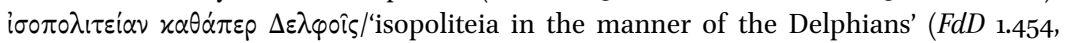
169-81 BCE).

$51 \quad$ Rhodes and Lewis 1997, 134-135; Grzesik 2018b, 117-139.

$5^{2} \quad S_{y l l^{3} 221 C ; B C H} 73 \cdot 1949 \cdot 25^{8-26 o . ~}$

$53 \quad$ BCH 83.1959.155-166.

$54 \quad F d D 4.464$. 


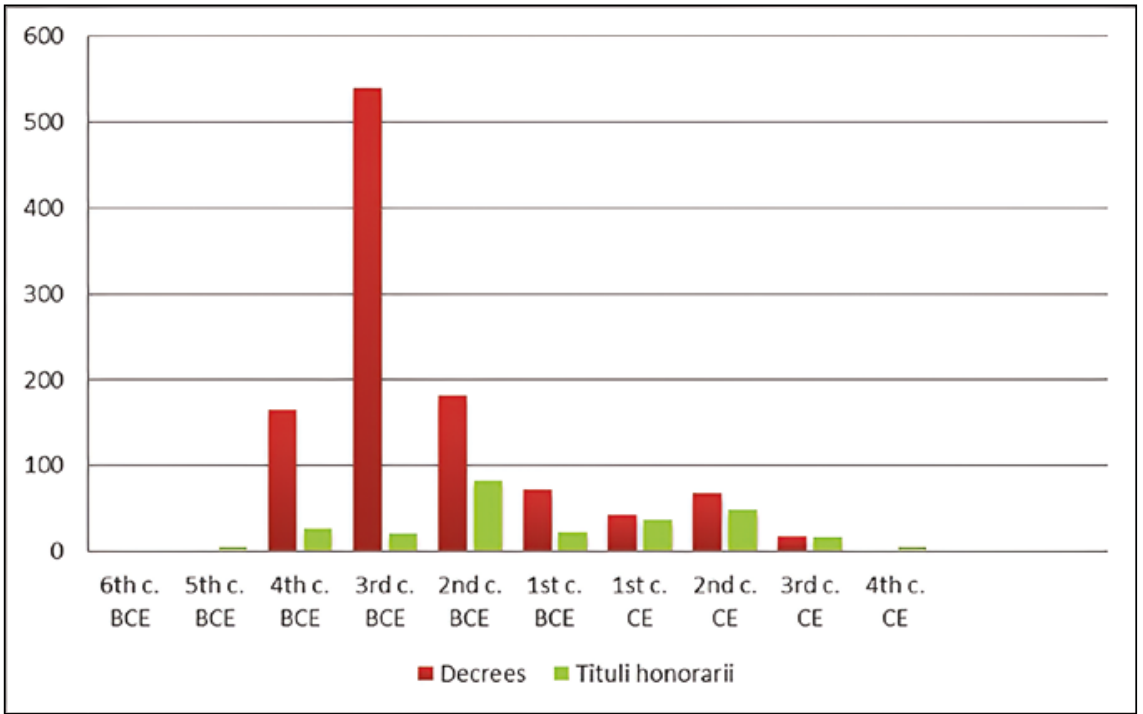

FIGURE 6 Decrees and tituli honorarii from Delphi by century

with numerous honorific decrees for high-ranking Macedonians ${ }^{55}$ reflect the strong Macedonian impact on fourth century Delphi. ${ }^{56}$

The abundant inscriptional evidence from the third century вСЕ, especially in its second quarter, shows that this century represents the golden age of the Delphic culture of honouring (Figures 1 and 4). Neither before nor after did the polis grant as many honorific decrees: nearly $45 \%$ of all decrees come from the third century. $\mathrm{Ma}^{57}$ and Jones ${ }^{58}$ have argued convincingly that the two centuries after the death of Alexander were an age of city-states. During this time, Greek poleis created a strong network of self-governing states that cooperated with one another in the form of interstate arbitration, the recognition of asylia, the dispatch of theoroi, and the practice of requesting judges from other cities. The vast majority of all Delphic decrees are proxeny decrees which reflect these peer-polity integrations within the Greek poleis. ${ }^{59}$ Hundreds of texts from this period show honours given to foreign judges, sacred envoys or their hosts (theorodokoi), ambassadors, and foreign benefactors. In the

55 The citizens of Delphi also honoured Poulydamos (Tataki 1998, no. 13) and Polyperchon (Arnush 1995, 95-104).

56 Miller 2000, 263-281; Arnush 200o, 293-307.

57 Ma 2003, 9-39, especially 14.

58 Jones 1964, 4.

59 For proxeny in Greece, see Mack 2015. 
Hellenistic period, Delphi was a Hellenic centre in which Greek communities could advertise their Greekness and project their identities.

By the third century вСЕ, the Macedonian flavour had been replaced by an Aetolian one. After resisting the Gallic invasion of Delphi in 279 BCE, the Aetolian League assumed control of Delphi's territory, festivals, sanctuary's officials, and the Amphictyonic council. ${ }^{60}$ Between 279 and 190 BCE, $53 \%$ of all honorific portraits erected at Delphi were granted by the Aetolians. ${ }^{61}$ No other community had ever found itself in a position to impose itself over foreign public land and create its own sphere of influence in the way the Aetolians did at Delphi. The Aetolian domination of Delphi affected the topography of the sanctuary, as monuments relating to Aetolia were concentrated at the west end of the temple terrace, ranging over the entire landscape. ${ }^{62}$

The shedding of the Aetolian yoke after the battle of Magnesia in 19 о вСE fuelled the development of the local statuary habit. When the Delphians regained control over their own territory, festivals and finance, the civic elites arose from their slumber. This is reflected in the significant increase of civic benefactors that were praised for their benevolence towards the city. During this period, the number of portraits awarded by the Delphic polis increased from four (between 279-190 ВСE) to thirty (between 190-27 BCE). A similar tendency is discernible in the number of votive offerings dedicated by Delphic citizens: in the third century вСЕ there are only five examples, yet in the next century the number of dedications increased to ten. ${ }^{63}$

The epigraphic record of the second century BСE presents the largest number of inscriptions, mainly due to the considerable number of manumission records that appear at this time. More than 1200 slaves were manumitted at Delphi between $201 \mathrm{BCE}$ and $100 \mathrm{CE}$, which represented part of a much wider phenomenon. The majority, $71 \%$, were set free in the second century BCE by both Delphic citizens and foreigners; $20 \%$ were set free in the first century BCE; and only $9 \%$ were set free in the first century CE, mostly by local individuals. ${ }^{64}$ The number of recorded manumissions limited only to the period between $201 \mathrm{BCE}$ and $100 \mathrm{CE}$ is puzzling. Many scholars who have examined this issue suggest that the advent of Rome and the Greek economic situation at the time

\footnotetext{
6o Sifakis 1967, 65. Cf. Flacelière 1937, 367; Champion 1995, 213-22o.

61 E.g. $F d D$ 3.230, $F d D 4.130$ and 4.131, $F d D 4.165$ and 4.166a, $F d D$ 3.149. Cf. Grzesik 2018b, 117-139 and 2019, 200-227.

62 Grzesik 2018b, 117-139. See also Chapter 6.2.1.

63 Kyriakidis 2014, 121.

64 Zelnick-Abramovitz 2005, 148-15o. For manumissions at Delphi, see Mulliez 1992, 31-44, 1997, 93-102 and 2017, 13-30.
} 
impacted the number of manumissions. ${ }^{65}$ Does the high number of manumitted slaves in Delphi in the late Hellenistic period indicate that slave-owners were very wealthy or, on the contrary, that they were impoverished and could no longer afford to hold slaves? ${ }^{66}$ Or does the fall in the number of manumissions in the first century CE reflect economic decline in the region or in Greece in general, as Rostovtzeff has argued? ${ }^{67}$ Zelnick-Abramovitz claims that, apart from the economic factors, other elements also likely contributed to the growing number of inscribed manumissions in Thessaly from the second century BCE onwards, such as the need to monitor the non-citizen population. The procedure of registering the freed slaves on stone, and very likely also in the cities' archives, allowed cities both to monitor the ex-slaves and to make sure that they fulfilled their duties as non-citizen residents. ${ }^{68}$

None of these suggestions, be they economic, political, or social, adequately explain why an unprecedented number of manumissions compared with other poleis is preserved at Delph; ${ }^{69}$ furthermore, they neither explain why the Delphic records are limited to just three centuries nor why there was such a diverse chronological distribution of manumissions in Greece. Why, for instance, are there only a few recorded manumissions from the last two centuries вСЕ, outside of Delphi and Aetolia, where they appear regularly? Conversely, why do manumission numbers increase during the first century CE onwards in Thessaly and the Bosporan kingdom, yet decrease at Delphi? Finally, no explanation has yet been given for why there are no recorded manumissions after the fourth century вСE in Athens. ${ }^{70}$

I argue in later chapters that the unprecedented number of over 1200 manumissions preserved at Delphi is most probably the result of the Delphic publishing habit, which was more developed there than anywhere else; the citizens of Delphi carved more proxeny decrees and more manumission records on stone than the rest of the Greeks. Moreover, the location of proxeny and manumission records (building walls instead of free-standing stelai) increased their chances of survival. When the manumission inscriptions made their appearance at Delphi, the number of proxeny decrees voted on fell by

\footnotetext{
65 Westermann 1955; Hopkins 1978; Zelnick-Abramovitz 2005; Bresson 2019, 251-277.

66 Vogt 1975, 42.

67 Rostovtzeff $1941,625-626$.

68 Zelnick-Abramowitz 2013, 128-132.

69 Thessaly ranks second with 313 inscriptions from various cities, corresponding to over 176o acts of manumission, see Zelnick-Abramovitz 2013, 29 and Appendix. Boeotia reveals 173 manumission records: 125 from Chaironeia, sixteen from Koroneia, and fourteen from Orchomenos. See Szeląg, forthcoming.

Zelnick-Abramovitz 2005, 64 .
} 
$65 \%$ compared to the previous century, depriving the city of part of its income and benefactions. The events of the late third and early second centuries BCE may thus have compelled the citizens of Delphi to extend their established and 150-year-old business of publishing honorific decrees to include a new category of inscriptions, in order to find a new source of profits. In Thessaly, Orchomenos, Kos, and Nikaia money was collected on the occasion of the publication of the manumission record. ${ }^{71}$ Perhaps also in Delphi the fee for inscribing an act became a part of the whole manumitting procedure from the second century BCE onwards, although there is no direct evidence for this in the preserved material. ${ }^{72}$ This particular field of inquiry, however, deserves investigation with regard to other Greek liberation acts in terms of local publication and epigraphic habits, which will help to situate the Delphic manumissions within a wider historical and geographical context.

The number of manumissions distorts the total number of texts from the second century ВСЕ and offers a misleading impression of the largest recorded peak (Figure 1), while the number of inscribed decrees fell by $65 \%$ compared to those in the third century. At the same time, there was a significant increase in the number of tituli honorarii (Figure 6). This result must be considered from several angles. As mentioned previously, the end of Aetolian control at Delphi fueled the development of the local statuary habit. ${ }^{73}$ The vast majority of statues were granted to members of the Delphic upper class, which attests to the ever-growing influence of the civic elite within the Delphic community. ${ }^{74}$ At the same time, however, a considerable number of statues commemorating Roman officials appeared at Delphi. Generally, the second century BCE was a difficult period for Greek poleis. The Second Macedonian War seems to have been the most destructive event, especially for Athens, as not one decree from these years has survived. ${ }^{75}$ The battle of Pydna in 168 вСЕ changed the political situation in the region. Greece witnessed the fall of the Hellenistic monarchs and the rise of a new empire. The citizens of Greek cities thus had to find a way to cooperate with the new power that was taking control of their land.

One way to gain favour with Rome was by offering honours to its powerful representatives. All high-ranking Roman generals from the first half of the second century в СЕ who were involved with Greek affairs (M'. Acilius

71 This possibility is less certain in Egypt, Tithora, and Elateia, and perhaps also in Athens, see Straus 1973, 143-145 and 2009, 233-239; Quenouille 2002, 67-97; Zelnick-Abramovitz 2013, 71-107.

72 For discussion, see Grzesik, forthcoming.

73 Kyriakidis 2014, 121; Grzesik 2019, 200-227.

74 E.g. FdD 4.242 (c. 189 BCE); Daux 1936, 453. Inv. 1763+949 unpublished titulus honorarius.

75 Tracy $2015,13$. 
Glabrio, ${ }^{76}$ T. Quinctius Flamininus, ${ }^{77}$ L. Aemilius Paullus ${ }^{78}$ ) were commemorated at Delphi with honorific monuments. This foreshadows a change of the entire epigraphic tradition at Delphi, which was now concentrated on prominent Romans. Neither Roman officials, nor Roman emperors needed the kinds of honours granted in decrees. Apparently, honouring them with outstanding honorific portraits and monuments was enough. This explains both the decline in the number of inscribed decrees and the increased number of tituli honorarii. Whilst engaging with Rome, Delphic interactions with the wider Greek world seemed to shrink; the number of foreigners that were honoured at Delphi decreased by $40 \%$. Furthermore, among the beneficiaries of Delphic honours, we find mainly inhabitants of mainland Greece, and we note an almost total absence of citizens from Asia Minor or Africa, who were attested regularly in the preceding period. ${ }^{79}$ In the late Hellenistic period, the regionalisation of Greece replaced Panhellenisation, and the once cosmopolitan Delphic sanctuary was reduced to the status of a much more local shrine. The economic and political recession encountered by Greece in the wake of the Mithridatic Wars is mirrored in the reduced number of inscriptions in the first century ВСЕ (Figure 1).$^{80}$ The remarkable decline of coin production in Greece from the mid-second century вСЕ to the first decades of the next century provides evidence of financial troubles. ${ }^{81}$ War always results in economic hardship due to its nature, such as by increasing the demand for food and manpower, interrupting trade, destroying infrastructure and interfering with travel. ${ }^{82}$ The Pythian Games of 86 вСЕ were cancelled due to ongoing war, which prevented people from travelling to Delphi. ${ }^{83}$

The quarter-century period $\left(75^{-5}\right.$ О BCE) which saw the end of the Mithridatic Wars was one of the lowest points of epigraphic production at Delphi. The number of inscriptions remained low until the reign of the Flavian dynasty. At some point between the mid-first century в СЕ and the mid-first century $\mathrm{CE}$, there was a significant change in the local political culture, and Delphic democracy gradually took an oligarchical turn. ${ }^{84}$ The honorific decree granted to Telesagoros of Abai bears witness to the fact that, during the mid-first century $\mathrm{CE}$, the citizen body was already divided into two hierarchical groups:

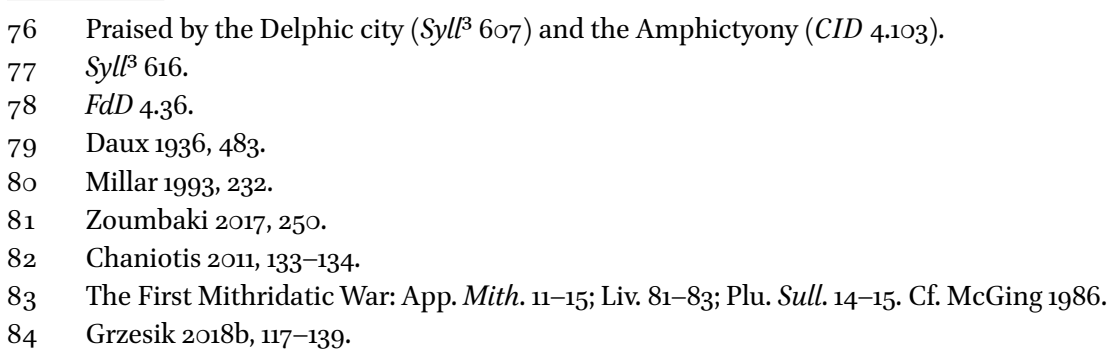


the damiourgoi, - who had exclusive access to the highest civic offices and priesthood, and the rest of the population, who were denied any opportunity to undertake these prestigious functions. ${ }^{85}$ This decree also reveals the problem of depopulation at Delphi in the first century CE. ${ }^{86}$ This problem, which is attested in many other contemporary documents, must have been significant as Claudius remarks on the issue in his letter addressed to the Delphic citizens. ${ }^{87}$ The depopulated city had to face the new established order in Greece under Augustus, who accomplished the following: the formation of a new Roman province; the foundation of Nikopolis and its inclusion in the Amphictyony; the creation of the 'Actia', a new festival added to the circuit of Greek Panhellenic games; and the spread of the imperial cult. New religious and festival centres reduced both the fame of Delphi and the numbers visiting the sanctuary. Fewer visitors meant less money, which resulted in the impoverishment of the whole community. The epigraphic habit, like a mirror, reflected these difficulties.

The imperial period can be explored through the quarter-century graph (Figure 2) or through the chart which dates the number of inscriptions according to the reign of individual emperors (Figure 7) supplemented with Table 2 which reveals the average number of inscriptions per year per emperor. This separation of inscriptions enables one to detect changes that may have been overlooked in the quarter-century graph.

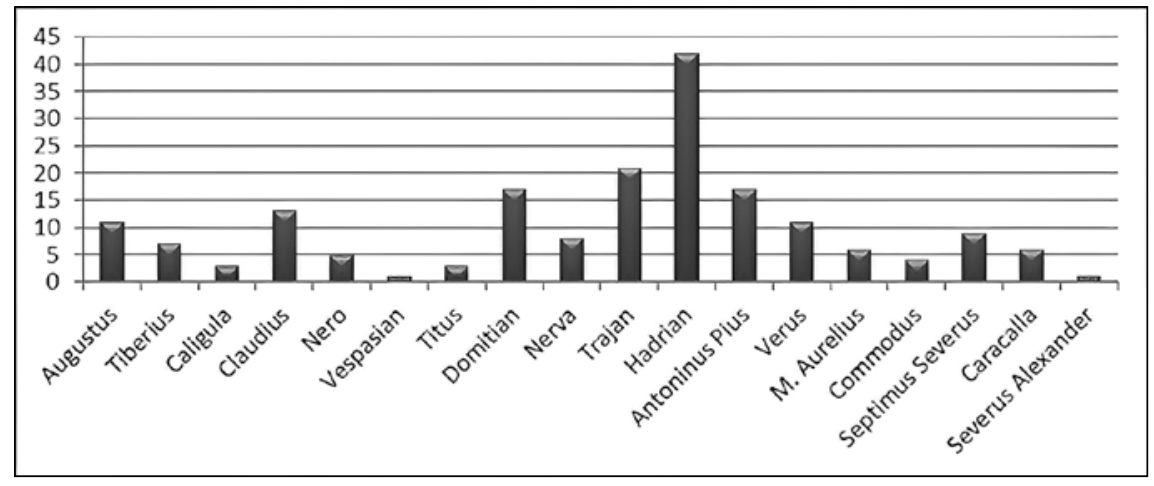

FIGURE 7 Inscriptions from Delphi dated to the reign of particular Roman emperors (without manumissions)

Note: Only inscriptions that can be dated to the reign of particular emperors are included.

$\begin{array}{ll}85 & F d D \text { 4.442. } \\ 86 & \text { Alcock 1993. } \\ 87 & F d D \text { 4.286. Sartre 1991, 233-237. }\end{array}$


TABLE 2 The average number of inscriptions per year per emperor

\begin{tabular}{ll}
\hline Emperor & No. of inscriptions per year \\
\hline Augustus & 0,28 \\
Tiberius & 0,31 \\
Caligula & 1 \\
Claudius & 1 \\
Nero & 0,38 \\
Vespasian & 0,1 \\
Titus & 1,5 \\
Domitian & 1,1 \\
Nerva & 8 \\
Trajan & $\mathbf{1 , 1}$ \\
Hadrian & 2,1 \\
Antoninus Pius & 0,8 \\
Verus & $\mathbf{1 , 6}$ \\
M. Aurelius & 0,3 \\
Commodus & 0,3 \\
Septimius Severus & 0,7 \\
Caracalla & $\mathbf{1}$ \\
Severus Alexander & 0,08 \\
\hline
\end{tabular}

In Figure 7 we can see that a peak in the last quarter of the first century CE should not be attributed to the entire Flavian dynasty, but only to the reign of Domitian. Vespasian was declared emperor by the Senate after a tumultuous year in Rome. ${ }^{88}$ Titus, who succeeded his father, ruled for only two years, yet the number of inscriptions from this two-year period slightly grows (Table 2). The peak between 76 and 100 CE can be linked with Domitian's (and Nerva's) building activities throughout the empire. ${ }^{89}$ At Delphi, the aqueducts, a fountain, the house of Pythia, the library, and the structorium were re-built, which increased the number of inscribed texts. ${ }^{90}$ Domitian himself was also involved in the reconstruction of the temple of Apollo. ${ }^{91}$

88 On the year of the four emperors, see Morgan 2006.

89 On Flavian building activity in the Peloponnese, see Pawlak 2011, 324.

9o Syll 813 C; $C I D 4.141$, CID $4.146-8$.

$91 \quad F d D$ 4.120. 
The Antonine peak, which is widely attested elsewhere, is also discernible in Delphi. ${ }^{92}$ It may seem that during Nerva's reign there was a marked decline in the number of inscriptions; however, he was emperor for only one year and four months, and so the total number of inscriptions inscribed in each year of his reign is much higher than the number of texts inscribed during Domitian's imperial reign of fifteen years (Table 2). Over $6 \circ \%$ of all inscriptions from the Antonine period derive from official letters between Delphi and Rome ${ }^{93}$ and the honorific statues of the ruling family. ${ }^{94}$ In the last quarter of the first and throughout the second century CE, we encounter the highest number of decrees in comparison with the preceding centuries (Figure 6). This is due to the fact that oligarchy was firmly established in Delphi, while Greece as a whole was experiencing a period of peace and prosperity. ${ }^{95}$ The transition to oligarchy reached its apogee during the second century CE in Delphi. Prosopographical studies reveal the domination of several prominent families, whose members (both male and female) often held priesthoods and civic magistracies; these roles were often performed simultaneously, and at times successively. ${ }^{96}$ Delphi's elite took full control over civic life. A similar accumulation of power and land by wealthy local families can also be seen in other Greek regions, especially in Athens, Olympia, and Asia Minor. ${ }^{97}$ These changes are reflected in the statuary habit, as the wealthy citizens of Delphi funded portraits for members of their families and were granted honorific statues by the community for their benevolence towards the city.

The second century CE witnessed Delphi's renaissance. During this time, the number of statues erected in Delphi increased, while the spectrum of both those who granted portraits and those who were honoured with them expanded. Delphic women were also more generous with their donations than ever before. After an absence of more than 16o years, the citizens of distant Mediterranean areas appeared again in inscriptions. Among the founders

92 See Komar 2020, 68-80; Głogowski 2020, 166-183; and Porucznik 2020, 81-101. Cf. Hedrick 1999, 407 .

93 E.g. $F d D$ 4.300, $F d D$ 4.305-306.

$94 I G$ XIV 105o. Nerva $B C H$ 76.1952.627,2; Trajan CID 4.149 and Syll ${ }^{3} 825$ B; Hadrian Syll ${ }^{3} 829 \mathrm{~B}$, Syll ${ }^{3} 835^{\mathrm{B},}$ Syll ${ }^{3} 835 \mathrm{~A} ; F d D 4.472$.

95 This is attested in the legislative activity of the boule, which acted only as an advisory board from the fourth century вСE until the late first century СЕ.

96 E.g. the Memmii FdD 1.466[2] and the Gellii $B C H$ 87.1963.202.

97 Asia Minor: Sillyon (IGR III 800 and 801), Knidos (SGDI 3549), Argos (SEG 11.314). Cf. Quass 1993, 349; Zuiderhoek 2009, 53-70. For Roman Athens, see Geagan 1967, 32-61 and Woloch 1969, 503-510. For Roman Olympia, see Zoumbaki 2001, 65 . 
of honorific portraits we find inhabitants of Phrygia, ${ }^{98}$ Cyprus, ${ }^{99}$ and Ionic poleis. ${ }^{100}$

Another decrease in epigraphic production occurred during the reign of Marcus Aurelius and Commodus. Some scholars have argued that the decline was caused by the Antonine plague, ${ }^{101}$ but it is not known how widespread that plague was in Greece. It seems that it did not cause a very great shortage of manpower in central Greece, even though Athens was one of its major victims. ${ }^{102}$ There is no doubt that the plague caused great harm to Rome and the entire Apennine peninsula, and therefor to the wider economic system of the empire, and, therefore, the plague might be considered the principal reason for the decrease in epigraphic production at Delphi. The epigraphic culture was always linked to the economic situation of the city and the region.

Under Septimius Severus and Caracalla another rise in the epigraphic curve is discernible, which coincided with the temple renovation approved by Cn. Claudius Leonticus. ${ }^{103}$ At the beginning of the third century CE, we still have the entire spectrum of both public and private inscriptions (albeit in small numbers), yet in the second half of the century a significant change took place (Figure 8). Tituli honorarii granted exclusively by the Delphic polis still appear, but the private epigraphic tradition ceases to exist after this time. In addition, decrees ceased to be inscribed after $c a .250 \mathrm{CE}$. The rapid increase in inscriptions at the beginning of the fourth century $\mathrm{CE}$ was due to thirteen bilingual inscriptions which appeared along with the text of the edict of Diocletian, ${ }^{104}$ while the peak between ${ }^{2}{ }^{26-35}$ O CE was the reflection of four surviving statues of Constantine the Great and his relatives. ${ }^{105}$ Images of Valens and Valentinian I from $365 \mathrm{CE}$ are not only the last honorific monuments set up within the temenos at Delphi, but they are also the final inscriptions that belong to the epigraphic habit of the site in antiquity. ${ }^{106} \mathrm{~A}$ number of Christian texts were found in Delphi (one example being the epitaph of the Christian

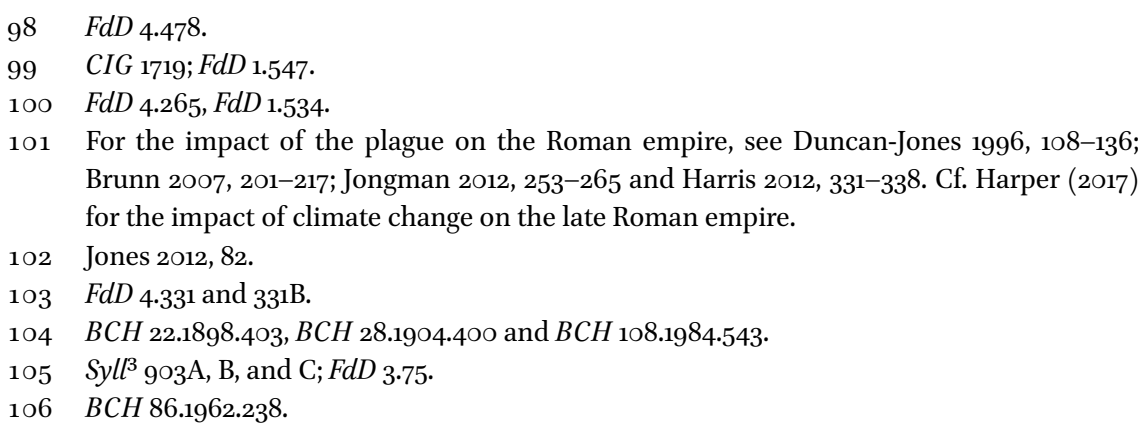




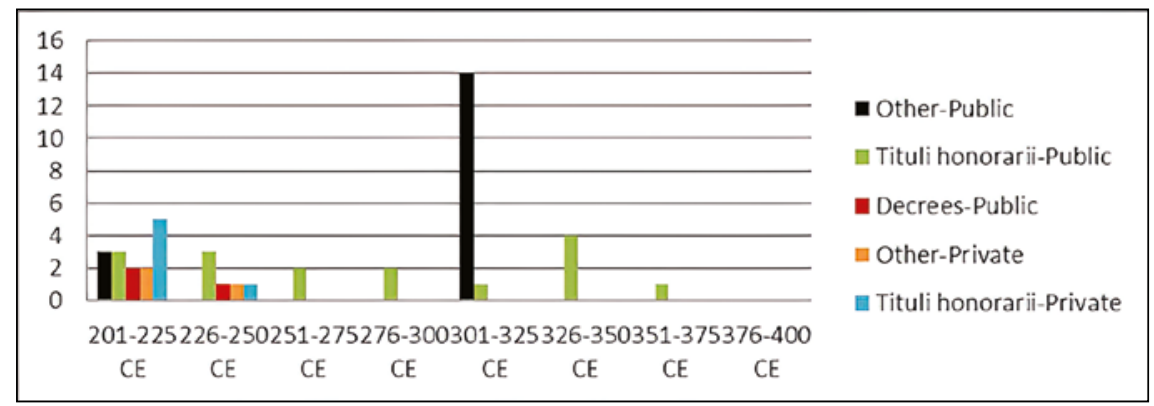

FIGURE 8 Public and private inscriptions from Delphi dated to the third-fourth centuries CE

deaconess), but their character belongs to a different epigraphic tradition, and therefore, they are excluded from this study. ${ }^{107}$

\subsection{The End of the Epigraphic Habit and Honorific Culture at Delphi}

There is a modern idea that ancient culture did not 'fall', but 'transformed.'108 Both the epigraphic habit and honorific culture at Delphi, however, did fall: by the mid-fourth century CE they were gone. The end of the epigraphic habit at Delphi marked the culmination of a long-term process that was already under way at the start of the first century вСЕ, when the first significant ebb occurred. Among the catalysts that accelerated this process, one should mention the political crisis which had a heavy impact on the Roman and Greek economies. Moreover, the hyperinflation of the late third and early fourth centuries CE was an obvious threat to honorific culture, as prices increased at an alarming rate. ${ }^{109}$ The central administration grew quickly and the shift of power to a centralised bureaucracy limited the ability of communities to manage their own finances. Valentinian and Valens' new regulation regarding the transferal of two-thirds of civic funds to the imperial fisc weakened the financial situation of Greek poleis. ${ }^{110}$ All these factors caused great harm to Greek honorific culture. The decree culture ended at Delphi in $c a .250 \mathrm{CE}$, while by the late fourth century CE the statue habit had practically disappeared, even though

107 BCH 23.1899.273 (c. 400-45O CE). For the epigraphic habit of late antiquity, see Bolle, Machado, Witschel 2017, 15-30.

108 Remijsen 2015, 9 .

109 Wassink 1991, 465-467.

110 Schmidt-Hofner 2006, 209-248; Remijsen 2015, 147-164. 
in some Aegean regions the statuary tradition continued throughout the fifth and even into the early sixth century $\mathrm{CE}$, mostly in the provincial capitals, Constantinople and Athens, which were all cities that had a steady influx of money.11 The decline of civic traditions, allied with the spread of Christianity, foreshadowed the end of the entire honorific culture in antiquity.

Bryan Ward-Perkins has discussed in detail the factors that brought about the gradual expansion of Christianity which transformed society in late antiquity. He suggests that the statuary habit was most severely affected by factors such as the increased role of Christian bishops, the change in perception regarding traditional benefactions and new forms of Christian charity, and the diminished role that public space played within a community due to the increased role of Christian churches. ${ }^{112}$ The famous edict of Theodosius was the final nail in the coffin for Delphi's epigraphic habit, as it banned all religions except Christianity, closed all oracular shrines and forbade the organisation of the ancient games, considering them to be a relic of paganism. ${ }^{113}$ After this regulation no honorific portrait was set up on public land at Delphi, and the kind of epigraphic culture that had characterised Delphi over the preceding centuries came to its final end.

\subsection{Conclusion}

As a city as well as a sanctuary, Delphi had its own pattern of evolution, which was different from both the large urban centres and other major sanctuaries. Correspondingly, the epigraphic tradition at Delphi is notably different from that of other poleis. Various phenomena not only affected the shape of its epigraphic curve, but also had an impact on the categories and number of inscriptions that were preserved. These phenomena include the extent of excavation, the type of material onto which texts were engraved and the character of the site. Among the global factors that influenced the epigraphic habit at Delphi, one should mention historical events that occurred in the region and beyond, such as the Persian wars, which increased the volume of votive offerings in the fifth century BCE; the Macedonian and Mithridatic Wars that led to financial recession throughout Greece; and the third century crisis. The earthquake of $373 \mathrm{BCE}$, Aetolian dominance, and the oligarchisation of the city are local elements that contributed to the peaks and troughs of Delphic

\footnotetext{
111 Ward-Perkins 2016, 295-302.

112 Ward-Perkins 2016, 302-305.

113 Cod. Theod. 16.10.9. Connelly 2007, 81; Remijsen 2015, 147-164.
} 
epigraphy. The extraordinary number of manumission texts should also be highlighted as a local phenomenon which was subject to variation over time.

Let us now return to the initial question: Why does the honorific culture constitute the greatest proportion (43\%) of epigraphic production at Delphi? Similarly high percentages for honorific documents also occur in Ephesos, Olympia, Miletos, and Pergamon; however, none of these places produced more honorific decrees than tituli honorarii. In Ephesos ${ }^{114}$ tituli honorarii outnumber decrees by more than three to one, with the result that the imperial period is much better-represented than the rather poorly attested Hellenistic era. As with the case at Delphi, Boeotian decrees are also more numerous than honorific inscriptions and the peak of the Boeotian epigraphic curve also dates to the third century ВСЕ. ${ }^{115}$ The number of honorific texts from the whole of Boeotia (which is minimally reckoned at 805 inscriptions), however, cannot compare with the number of Delphic honorary texts (1465). ${ }^{116}$ Moreover, local civic bodies and private individuals prevail among the dedicators and authorities that granted honours in Boeotian cities. What was therefore so exceptional about Delphi that it shaped the extraordinary character of the local epigraphic culture? There can be no doubt, in my opinion, that the cosmopolitan character of the site is the answer to this question. At Delphi the citizens of the Mediterranean world compete with one another to be eternalised within the famous sanctuary of Apollo; only a Panhellenic shrine could provide a multi-ethnic audience and guarantee of publicity. ${ }^{117}$ Throughout the centuries Delphi served as a storyboard that told the history of Greece and its inhabitants, offering a sort of collective space for memory and much more besides. The Delphic temenos constituted the ideal spot to flaunt one's power, ambition and status. There was no better place, at least from archaic times to the late Hellenistic period, to advertise one's own Greekness than in Delphi. Through its honorific decrees Delphi brought communities together and forged a common Greek identity. Honorific culture allowed negotiations both internally (between the demos and the elite) and externally (between Delphi and outside agents) to take place. It facilitated the creation of a strong network of cooperation with other self-governing states, a trend which continued into the Roman period. Domingo Gygax's contributions regarding euergetism are particularly useful in understanding why Delphi produced so many honorific texts. As he observes, euergetism was an institution with two faces that involved an

\footnotetext{
114 Nawotka 2020c, 118-143.

115 Szeląg 2020, 31-51.

116 The number includes only honorific documents produced by the Delphians.

117 Grzesik 2018a, 23-42.
} 
exchange between benefactors (who funded benefactions for the city) and the poleis (who then honoured the benefactors). Its main characteristic, as a consequence, was reciprocity and for this reason most examples of euergetism we know of are attested by honorific inscriptions. ${ }^{118}$ Euergetism and honorific culture as a whole were therefore major social areas in which members of the elite could challenge one another. Rewards for benefactions turned into 'a race for honours' and such rewards came to function as prizes in euergetic contests. Moreover, there was no better international field for competition (and confrontation) than Delphi. Ultimately it must be stressed that behind every honour was the idea of improving the city through euergetism. ${ }^{119}$ The system of benefactions affected the city's finances, administration and the lives of the common inhabitants of the polis, inasmuch as it encouraged people to spend large sums of their private wealth upon the city.

It has been stressed on many occasions that Delphi's dual nature was another unique feature of the city's honorific habit. However, the local (Delphic) and the international (foreign) honorific habits developed independently, as is demonstrated by the practice of granting honorific portraits. The Aetolian domination over the sanctuary hindered the development of Delphic statue production for nearly fifty years. The shedding of the Aetolian yoke in 19 о BCE marked an important moment in the history of the local honorific habit, as the number of images set up by Delphians increased significantly after that time. This marked a symbolic shift of power towards wealthy city benefactors who from then on willingly founded sculpture portraits on public land..$^{120}$

Finally, despite the uniqueness of Delphi, there are several elements within the local honorific habit that corresponded to other broader trends that characterise the honorific culture of the whole of Greece. First, the epigraphic curve was never static and the inscriptions were not spread evenly throughout the period. Although a review of the maxima and minima of epigraphic output shows significant divergence among the particular case studies, the mid-Hellenistic peak is also typical for Boeotia, Mesambria on the Black Sea coast, some cities of western Asia Minor (Pergamon and generally Miletos) and, to a degree, Alexandria. ${ }^{121}$ Secondly, the Antonine peak, which is widely attested elsewhere, is also discernible in Delphi. ${ }^{122}$ Thirdly, the dramatic fall in the number of inscriptions after c. $25 \mathrm{O} \mathrm{CE}$ is a common feature of epigraphic

\footnotetext{
118 Domingo Gygax 2016, 2-3.

119 Domingo Gygax 2016, 223.

120 Grzesik 2019, 200-227.

121 Nawotka, Carless Unwin, Grzesik at al. 2020, 215-246.

122 E.g. in Olympia (Komar 2020, 68-89), Phoenicia (Głogowski 2020, 166-183) and Athens (Hedrick 1999, 407).
} 
production in other areas of the Greek-speaking east as well as Delphi. The wars of the mid-third century $\mathrm{CE}$ and the general crises of the empire were factors which led to the near demise of the tradition in Boeotia, Chersonesos, Olympia, Miletos and Pergamon. ${ }^{123}$ Lastly, there are two components of honorific culture that are always decisive: the dedicators and the recipients. As a rule, most epigraphic habits were focused on gods, ${ }^{124}$ dedications and votive offerings were also the first type of inscriptions to appear in Delphi and they dominate in the fifth century вСЕ. Together with the development of the entire tradition, the categories of honorands changed and widened and poleis used decrees to commemorate external benefactors, Hellenistic kings, royal officials, and various types of artists and athletes. This is reflected in the large number of Delphic proxeny decrees, especially in the third century все. Delphic decrees, which were typical of the Hellenistic times, were largely replaced by tituli honorarii in the imperial era. The decisive factor for the changing nature of the habit must have been the growing preference for monumental honorary forms among the Romans and municipal elites. ${ }^{125} \mathrm{~A}$ similar tendency is also discernible in Boeotia ${ }^{126}$ and Olympia. ${ }^{127}$ Then, due to the ongoing oligarchisation of Delphi and other parts of the Greek world, local wealthy benefactors came to embody the dominant group of dedicants and recipients of privileges in the imperial period.

123 Nawotka, Carless Unwin, Grzesik at al. 2020, 215-246. Cf. Mrozek 1973, 117-118; Meyer 1990, 74 .

124 Meyer 2013, 453-505; Nawotka, Carless Unwin, Grzesik at al. 2020, 215-246.

125 Ma 2013, 4-7.

126 Szeląg 2020, 31-51.

127 Komar 2020, 68-89. 